\title{
Peak-Load versus Discriminatory Pricing: Evidence from the Golf Industry
}

\author{
Frank F. Limehouse \\ DePaul University \\ Michael T. Maloney \\ John E Walker Department of Economics \\ Clemson University \\ and \\ Kurt W. Rotthoff ${ }^{1}$ \\ Stillman School of Business \\ Seton Hall University
}

Last working version, final version published in:

Review of Industrial Organization Vol. 40, No. 3, May, Pages 151-165

Published in the Review of Industrial Organization

"The final publication is available at www.springerlink.com"

\footnotetext{
${ }^{1}$ Corresponding author: Kurt W Rotthoff: Kurt.Rotthoff@ shu.edu or Rotthoff@gmail.com, 400 South Orange Ave, JH 621, South Orange, NJ 07079; phone 973-761-9102; fax 973-761-9217. Frank Limehouse can be reached at flimehouse@gmail.com and Michael T Maloney at maloney@clemson.edu.
} 


\begin{abstract}
Using a unique dataset on the golf industry we analyze the weekend premium in golf course fees. Since both peak-load pricing and price discrimination may be at play, we attempt to separate these two forms of pricing. We find that as competition increases there is a decrease in the weekend premium, which we attribute to price discrimination. Additionally, we find that resort courses and courses that are heavily dependent on tourism have less differential pricing, which we attribute to less peak demand and less peak-load pricing.
\end{abstract}

Key Words: Golf , Peak-Load Pricing, Price Discrimination JEL: L11, L83, L33 


\section{Introduction}

Price differentiation among the same or similar products is not a new concept. The ability to charge different prices to different consumers maximizes producer surplus and reduces dead weight loss. However, as pointed out by Bailey and White (1974), price differences between consumer groups can be driven by price discrimination or by a natural differentiation across consumer groups based on an aggregation of consumer valuation, as in the case of peak-load pricing. This study analyzes the issues of price differentials in the golf industry, specifically focusing on the weekend-to-weekday ratio of green fees in order to distinguish between price discrimination and peak-load pricing.

Effective price discrimination requires three fundamental properties: market power, information, and consumer separation. ${ }^{2}$ Separation is the key, and for our venue of inquiry it is easily achieved.

Peak-load pricing is another form of differential pricing, but differs from price discrimination in several ways: First, peak-load pricing in the limit is akin to the joint products case (beef-and-hides), where price is determined by relative demand intensity for the common product being supplied. In the beef-and-hides case, the common product is a steer; in electricity the common product is generating capacity. In our case, the common product is the golf course. In peak-load pricing, price differentials are not driven by marginal revenue but rather by marginal valuation. Second, in peak-load pricing, separating consumers is not an issue. Consumers are naturally separated by the time of

\footnotetext{
${ }^{2}$ Although market power is a requirement, this does not restrict it to only monopolies (Borenstein 1985).
} 
demand. ${ }^{3}$ Pricing in the golf industry across weekdays and weekends also involves differences in demand times.

This study uses a unique dataset of golf courses to examine the determinants of the weekend to weekday price differential. We attempt to distinguish the pattern of price differentials between peak-load pricing and standard price discrimination. We view many of our determinants as factors that shift or smooth demand from the weekday to weekend, which leads to a traditional peak-load pricing story. However, other factors are seen as indicators of different demand elasticities that can be separated between weekdays and the weekend; this indicates that part of the price differential is discriminatory and not only peak-load driven.

We find that the degree of golf course competition reduces the amount of price dispersion, indicating that at least some of the differential pricing in golf is discriminatory. Concurrently, smaller weekend-to-weekday differentials are observed for golf courses that are heavily dependent on tourism. We argue that tourism is associated with less peak demand and thus is associated with less peak-load price differentiation.

The next section discusses the theory of price discrimination and peak-load pricing. Section three presents the model and data. The results are presented in section four, and the last section concludes.

\footnotetext{
${ }^{3}$ For instance, in the electricity generation industry, without convenient storage, the ability to arbitrage prices at different points in time does not exist (see Steiner 1957, Hirshleifer 1958, Buchanan 1966, Maloney 2001, and Gilbert and Newbery 2008).
} 


\section{Theory \& Literature}

The distinction between peak-load pricing and ordinary price discrimination is problematic. In both cases, price differentials exist and are driven by consumer groups with different intensities. However, under peak-load pricing, calculating the market equilibrium is similar to a joint-products model because price differentials across consumer groups aggregate to cover the cost of a common input. The different prices reflect different marginal valuations. With peak-load pricing, the price differentials shift demand to the extent possible to equalize the load, but the remaining difference in demand intensity between on- and off-peak consumption is priced based on relative marginal valuations.

Under price discrimination, the aggregation of different prices may also cover a common cost, but the price differentials are based on relative marginal revenues. Ramsey pricing in which relative prices are based on the ratio of the difference between marginal revenue and marginal cost is arguably the equilibrium tendency (Borenstein and Rose 1994, Stavins 2001, and Leslie 2004). To the extent that price differentials vary on the basis of competition, we claim that price discrimination is the dominant force.

Many empirical studies have attempted to model the impacts of competition and other determinants on price differentials. Bergstrom and MacKie-Mason (1991) allow for substitutability between on- and off-peak consumption to compare equilibrium capacity under uniform and time-of-day pricing. They find that peak-load pricing can reduce the price of a service during both peak and off-peak times when that service is constrained to operate with a fixed rate of return on capital. They also find that the capacity produced under peak-load pricing is ambiguous relative to a single price case. 
Another empirical analysis in pricing is Borenstein and Rose's (1994) paper on price dispersion in the U.S. airline industry. Their analysis provides strong evidence that most of the price differentials in the airline industry are not explained by cost variation. They use a hedonic regression of ticket prices on market structure and ticket characteristics and find a positive relationship between price dispersion and the number of competitors in the market. The authors also find that price dispersion decreases as the number of flights offered on a particular route grows.

In a related study, Stavins (2001) gets the similar result that market concentration lowers price dispersion. She finds that airlines on more competitive routes are forced to lower fares to elastic demanders (tourists), but are able to keep prices high to inelastic demanders (business travelers) due to brand loyalty and frequent flyer programs. Her results seem consistent with Busse and Rysman's (2005) study of competition and its effects on second degree price discrimination. They find that as competition increases in the market for yellow page advertisements, the prices for both small and large ads drop, but that purchasers of larger ads pay more (per unit of space) than do purchasers of smaller ads.

In other studies on the empirical relationship between market structure and price discrimination, Shepard (1991) uses data on over 1,500 multi-product and single-product gasoline stations near Boston to examine whether cost-side variations explain differences in prices between self- and full-service gasoline stations. ${ }^{4}$ Her results show that price differentials at multi-product stations are 9 to 11 cents higher than differences across single-product stations, indicating that high differentials at multi-product stations are not

\footnotetext{
${ }^{4}$ Multi-product gasoline stations offer both full- and self-service gasoline, whereas single-product stations offer only self- or full-service.
} 
cost-driven. Borzekowski et al. (2009) examine competition and pricing in the market for mailing lists, where purchasers can select (at higher prices) subsets of mailing lists based on consumers' expenditure on catalog purchases and the timing since last purchase. They find a positive relationship between competition and the probability that firms offer higher priced (consumer selected) lists. Likewise, for those firms that do offer select lists, the number of select lists that are offered to consumers increases with competition.

Although these previous studies have dealt with forms of price discrimination over time, other research focuses specifically on peak-load pricing. Peak-load pricing is found (among others) in the energy, airline, and water distribution industries (Arellano and Serra 2007a and 2007b, Berry and Mixon 1999, Escobari 2009, and Chong et al. 2004). These empirical papers provide substantial support for the Borenstein (1985) notion that many factors other than monopolistic power have important impacts on price dispersion in relatively competitive industries. These analyses also demonstrate that there exists little in economic theory that explains the relationship between market concentration and price differentials. It appears that this relation is idiosyncratic to industry-specific conditions, and thus most of the literature in this area remains largely empirical.

The pricing structure in golf has been analyzed by Shmanske (1998). This research is expanded by Shmanske (2004), who looks at the population's effect on the demand for golf courses, and by Limehouse et al. (2010), who separate the demand and supply effects for golf. We continue this expansion by analyzing both price discrimination and peak-load pricing by golf courses. 


\section{Model and Data}

Price differentials for a round of golf occur on several margins: (i) two-part pricing, where a front-end fee is charged for memberships; (ii) price differentials, where green fees are higher for weekends as compared to weekdays; and (iii) market segmentation where courses charge 9-hole players a higher price per hole than is charged to 18 -hole players. ${ }^{5}$ We focus on the determinants of weekday-to-weekend pricing in order to distinguish between price discrimination and peak-load pricing.

In many cases, golf demand varies significantly between the weekend and the weekday, especially at certain types of courses. This is largely due to the substantial time required to play a round of golf (approximately four-six hours) and the need to coordinate schedules among two-four individuals. Typically, the weekend demand for golf is higher and more inelastic due to the value of time on the weekend and the availability of matching with compatible partners. The inability simply to substitute a weekday for a weekend is conducive to peak-load pricing. At the same time, different demand elasticities present the opportunity for price discrimination between weekends and days that may play a role in any observed price differentials.

To distinguish between these two types of price differentials, we compute the ratio of weekend-to-weekday golf fees. We relate this measure to several variables that shift demand from weekdays to the weekend and also variables that may lead to different elasticities of demand between these two time periods.

\footnotetext{
${ }^{5}$ Golf course membership pricing has been addressed by Mulligan (2001), where he examines the efficiency of golf course membership pricing. He points out that membership fee pricing is not necessarily inefficient once one takes into account the time costs of members. Membership fee pricing limits the amount of play and creates a positive spillover to club members. Indeed, these are not the only forms of pricing that are found on golf courses. Many courses, for example, offer student and senior citizen discounts, and other courses bundle golf with other club amenities such as tennis, swimming pool, and dining privileges.
} 
While cost differentials could exist between weekends and weekdays, they are not likely the primary source of price differentials: First, the principal costs of producing golf are fixed: the land and maintenance of the course. Second, labor is such a small component of production costs that, even if there were a weekend premium paid to labor, the effects on costs can be presumed to be very small. This is especially true because most of the labor employed on the weekend is not highly skilled. Third, other variable factors, like water, are not priced differently on weekends and weekdays. ${ }^{6}$

Golf courses, as with firms in many other industries, face significant commoncost pricing and sunk-cost recovery. The marginal cost of putting another golfer on the course is much less than the average cost (or long-run marginal cost) of full production, which includes course construction and maintenance. To the extent that this phenomenon serves as a barrier to entry into the industry (in the spirit of Baumol and Willig 1981) is not a primary focus of this study. We believe that there are significant and substantial costs of entering the golf industry and that these costs enable golf courses to practice several different forms of price differentiation at any given moment in time. That is, even while the industry might earn zero economic profit, given the fixed number of firms, each faces a less-than-perfectly-elastic demand curve that can be segmented or otherwise exploited for additional revenues. The ability to price discriminate comes from these differing elasticities and because consumers cannot arbitrage price differences away.

A key variable in our analysis is the extent of competition. We argue that increases in competition will lower the degree of price differentiation in the price discrimination paradigm and serves as a test of price discrimination. Competition increases the elasticity of demand for any given course, thus reducing the course's ability

\footnotetext{
${ }^{6}$ Even so, we measure the amount of rain in the area to control for cost.
} 
to separate customers. To measure competition we use the total number of courses

located in the market area. Market area is defined as the MSA in major metropolitan areas or the county in smaller market settings.

We also have data on demographic variables in the market area. These include per capita income, population and population per square mile, and accommodation employment. Income, population, and population density are variables used to identify price discrimination. In general, when overall demand is higher, firms can charge higher prices in one market setting and lower in another, thereby inducing high and low demanders to separate themselves. ${ }^{7}$ Higher prices on the weekends force the lower intensity demanders to the weekdays. This works as a price discrimination strategy if weekend play and demand intensity are positively correlated. We measure demand intensity by income and population; both should be positively related to the weekend/weekday price ratio. The effect of population density is similar to competition. High population density in the market area reduces transportation costs between courses and is expected to have a negative sign.

On the other hand, accommodation (e.g., hotel) employment is a proxy for tourism, and tourism is expected to affect pricing through the peak-load pricing route. Areas that have more tourism arguably have less disparate demands between weekends and weekdays and, hence, are expected to have smaller weekend price premia.

We also measure the tourism effect by course classification. We separate golf courses into four groups: Resort, Private, Semi-private, and Public. ${ }^{8}$ We expect that there

\footnotetext{
${ }^{7}$ The dollar menu at fast-food places is an example. People who are willing to eat anything, eat cheap. People who are picky pay more most of the time.

${ }^{8}$ The type of course is self-reported by each individual course in the data. We exclude military courses because there are too few military courses and little pricing variation.
} 
is much less difference between weekend and weekday demand at resort courses. Hence, under the peak-load model, there should be significantly less differential pricing. We expect private courses will closely follow this resort-course effect. Members of private clubs are less likely to be constrained to weekend play than are patrons of public and semi-private clubs.

We have several measures that identify course characteristics that can indicate quality and potentially differentiated products. These include men's slope, ${ }^{9}$ whether the course is closed on Mondays, the course is periodically aerated, ${ }^{10}$ and if the course has: an enforced dress code, bar, driving range, caddies available, homes on the course, and certain environmental certifications. The environmental certifications follow Limehouse et al. (2010): They identify whether the course is an Audubon sanctuary, and undertakes standard or extended environmental planning.

Most of these variables are included as controls, and we do not make specific predictions about their expected effects. Quality differentials can lead to traditional forms of price discrimination, but we also believe that some of these quality measures may be more representative of traditional forms of peak-load pricing in that they influence how demand is shifted or smoothed across the peak and off-peak time periods. For example, golfers that play at high quality courses may not be constrained to play on the weekends.

\footnotetext{
${ }^{9}$ A golf course's slope rating is one of the U.S. Golf Association's measures for course difficulty. Each set of tees on a golf course receives a slope rating. For this analysis we take the slope rating from the men's tees. Presumably, a course's difficulty may indicate quality (i.e., it may have more desirable aesthetic features like water hazards, sand bunkers, elevation changes, etc.), but this is not necessarily the case. The highest-quality golf courses in the United States are not the most difficult ones per se. We include this measure, not because we have a theory of its impact of the weekend price differential, but rather we would like to account for unobserved course characteristics that may not be measured by our other variables.

${ }^{10}$ Our dummy variable for aerate is an indicator for whether the golf course aerates its greens three or more times per year. Aeration is the process of puncturing the surface of the green to allow for more air circulation to the grass's roots. Arguably, higher-quality courses tend to aerate their greens more often. While the few days after aeration may be undesirable to golfers (due to punctures in the grass), it is generally beneficial to the long term quality and appearance of the turf.
} 
However, we do make specific predictions about a few of these additional variables. Closing the golf course on Monday is a way of equalizing demand between weekdays and weekends. We therefore include this practice in the peak-load pricing bin and it should have a negative effect on the price difference. The availability of caddies is the same as the private-course effect. Courses with caddies are exclusive; the effect on differential pricing is expected to be negative.

Similarly, the environmental variables measure exclusivity and are expected to have a negative sign. We like to call this the "Pebble Beach Effect."11 As shown in Limehouse et. al (2010), environmentally certified courses tend to be very high-quality courses, and certification itself may enhance reputation or act as a signaling device to convey standards other than environmental quality per se. Golfers who are afforded the privilege of playing extremely high-quality courses are unlikely to be constrained to weekend play. Thus, demand is likely to be smoother across weekdays and weekends. We expect to see less differential pricing because there is less peak demand.

To test the determinants of price differentials we estimate the following model:

$$
\begin{gathered}
\ln \left(\frac{\text { Weekend Price }_{\text {Weekday Price }}}{\text { We }_{i j}}=\alpha+\beta_{1 j} \ln \left(\text { Competition }_{i j}\right)+\beta_{2 j} \text { Income }_{i j}+\right. \\
\beta_{3 j} \ln (\text { Population })_{i j}+\beta_{4 j} \text { Density }_{i j}+\beta_{5 j} \text { Tourism }_{i j}+\gamma_{i j} X_{i j}+\varepsilon
\end{gathered}
$$

where the dependent variable is the natural $\log$ of the ratio of weekend-to-weekday green fees for each course, $i$, estimated together and separately for each course type, $j$. The vector $X$ comprises the course-specific effects. We estimate the model for all of the courses together, with and without dummy variables for course type, and also for each

\footnotetext{
${ }^{11}$ Pebble Beach Golf Course is a fully certified Audubon sanctuary and engages in no weekend-to-weekday differential pricing. In our data, Pebble Beach is classified as a semi-private course; but (as indicated by the results in Table 2) when including all courses in the model and controlling for course classification, the coefficient on fully certified courses remains negative and significant.
} 
course type independently. We include state-level fixed effects. Because a non-trivial number of courses do not engage in differential pricing between weekdays and the weekend, we use a tobit regression to control for the large number of ' 0 ' observations. We measure competition and population in natural logs because preliminary analysis shows that these variables exhibit non-linear effects. The models have been run both with and without the squared terms as opposed to logs. The alternative specifications give consistent results.

Table 1 outlines the predictions of our model. The main variables in the analysis are broken into price discrimination and peak-load categories, with the expected effect on the dependent variable.

[Table 1 here]

The data that are used for this analysis come primarily from a 2002 Sportometrics golf database of approximately 15,000 golf courses in the United States and Canada. ${ }^{12}$ There are over $100 \mathrm{club}$ and course fields that provide characteristics from green fees to dress code policies. The data were collected via a survey conducted by Golf Magazine. In addition to the database from Sportometrics, data from the Bureau of Economic Analysis, Bureau of Labor Statistics, and the United States Census Bureau are collected to provide demographic characteristics at the MSA and county level. Demographic data are from 2000. Following studies of the banking industry, we specify markets to be the MSA for urban areas with a population of more than 500,000 and the county for all other areas.

Table 2 reports summary statistics. The dependent variable in our analysis is the natural log of the ratio of weekend-to-weekday golf fees. Some courses require a cart,

\footnotetext{
${ }^{12}$ Sportometrics is a golf course consulting company that licensed their data to us for this project. We exclude the Canadian courses due to comparability restrictions relative to our other data sources.
} 
while others do not. To control for this, we add the cart fee to the 18-hole green fee for any course that offers a cart but does not require one. We drop courses that do not have golf carts, and include a dummy variable for courses that do have carts but also offer caddies. Also, there are a few courses that charge higher prices on the weekdays than weekends; these observations are dropped from the analysis. ${ }^{13}$ We eliminate all courses that are located at clubs with less than 18 holes and those courses that are under 5,000 yards from the men's tees.

[Table 2 here]

We report the dependent variable in log form because it is a useful description of the data. The mean of 0.15 says that on average weekend rates are 16 percent higher than weekdays. The distribution is skewed: Weekend and weekday rates are the same for over 25 percent of the observations.

The competition variable is Other Courses in the Market Area, where the market area is the MSA in big markets and the county in smaller ones. The market area with the most courses is New York with 451, followed by Chicago with 405 . The average number of competitor courses is nearly 100 . However, the median is only 45 .

The distribution of per capita income is fairly symmetric. However, the distributions of population and population density are skewed similarly to the competition variable. The median value for population density is 0.35 and for population, 0.695 , compared to the means of 0.81 and 2.38 , respectively.

\footnotetext{
13 There are six courses that engage in inverse differential pricing: one public, two private, and three semiprivate. We omit these to avoid confounding the estimation.
} 
Rain is measured in average inches per year. These data are taken from NOAA for the period 1971-2000 averaged over reporting stations within thirty miles of the course. This variable is included as a cost control.

For the other variables, we see that regardless of Old Tom Morris' dictum, few courses are closed on Mondays, and most have a bar, driving range, and aerate. ${ }^{14}$ The environmental variables have frequencies that are consistent with exclusivity.

We separate the data by the type of course, as discussed above. Resort courses make up only 5 percent of the sample. Public and semi-private courses comprise over half the sample.

\section{Results}

The first test of our model comes from a simple comparison of the pricing policies across all types of clubs. Table 3 shows the percent of time that weekends are priced higher than weekdays at different types of courses. Notice that the pattern is consistent with peak-load pricing. Resort and private clubs have differential pricing around half of the time, while public and semi-private clubs price differentially over 75 percent of the time. This is consistent with the peak-load pricing phenomenon. We expect that many resort clubs have nearly uniform demand throughout the week. There is no peak demand, so there is no peak-load pricing. Similarly, private courses are expected to have approximately uniform demand, which accounts for the absence of differential pricing in the data. Conversely, public and semi-private courses are expected to have more variation

\footnotetext{
${ }^{14}$ Tom Morris, Sr., known as "Old Tom," won the British Open four times and is credited with being the inventor of greens-keeping. He held the view that greens should be given a rest once a week just like people.
} 
between weekend and weekday demand. As expected, they are more likely to charge a weekend premium.

[Table 3 here]

It is interesting to note in Table 3 that when we look at our dependent variable, resort and private courses overall charge 12-13 percent more on the weekends, whereas public and semi-private courses charge 19-21 percent more. However, when we take out the courses that have no differential charge, the weekend premium is about the same for all courses. This suggests that peak-load pricing (or the absence of it) is a heterogeneous phenomenon even among the resort and private courses.

Tables 4 and 5 show the regression results following the model given by equation (1). Table 4 gives the regression for all courses, with and without course-type dummy variables. Of course we believe that course-type dummy variables should be included. Nonetheless, our variables of interest stand out in both specifications. Competition and population density, which are both predicted to have negative effects, do show negative effects. Income and population, which are predicted to have positive effects, also follow the predicted pattern.

[Table 4 here]

The negative coefficient on Competition supports the hypothesis that as competition decreases, the elasticity of demand facing any one course decreases. The lower elasticity of demand increases the probability that the course can separate elastic and inelastic demanders. Less competition leads to more price discrimination.

We measure the magnitude of the competition effect by looking at the predicted decrease in the dependent variable from doubling the number of courses. Using the 
estimated tobit regression, we double the number of courses from its mean while evaluating all other variables at their means. Doubling the number of courses decreases the predicted degree of price discrimination by 0.06 from the mean value of 0.15 , representing a decrease in price discrimination of 40 percent.

Price discrimination also increases in places with higher income and larger populations and decreases with population density. The magnitude of the income effect measured in the same fashion as the competition effect is +0.075 ; that is, doubling income increases price discrimination by 50 percent. One way to think about population and population density is to consider them as controls for the way that the competition effect is measured. For instance, as population density increases, it intensifies the effect of the number of courses by making more choices available to golfers. The magnitudes of both effects are very nearly the same as that for the competition effect.

The result on hotel and accommodation employment shows that as tourism increases there is less of a differential between the weekend and weekday price. This is consistent with the idea that tourism smoothes demand between weekdays and the weekend. Golfers on vacation are less likely to be constrained to play only on the weekend. Thus, courses in high tourist areas face a smaller difference in demands across these two time periods, and there is less peak-load pricing. Notice that the tourism effect is negative and significant even when the course-type dummy variables are included. The magnitude of the effect is -0.09 ; doubling tourism reduces differential pricing by 60 percent at the mean. 
The coefficients on the course-type dummy variables reflect what we saw in Table 3. Resort and private courses charge a lower weekend premium than do public and semi-private courses.

Other variables that we highlighted show some of the predicted results: The availability of a caddie has a negative and significant sign. This is consistent with our notion that caddies imply exclusivity and that the effect follows the peak-load pricing framework. The same is generally true for the environmental variables. Closed on Monday has the predicted negative sign in one specification, but changes sign and loses its significance when the course-type dummy variables are included.

In Table 5, we estimate the model separately for the four types of courses. We include all of the independent variables from Table 4 and control for state-level fixed effects.

[Table 5 here]

There are several important results shown in Table 5: First, nearly all of the main independent variables maintain their predicted signs and statistical significance. Competition, density, and tourism are negative; income and population are positive. Income and population are not significant in the resort equation, and density is not significant for private courses. Tourism measured by accommodation employment is statistically significant only in the public and resort equations. Still, the results continue to support the view that there are both price discrimination and peak-load pricing factors at work in determining price differentials.

Second, the magnitudes of the competition effect are smallest for the public and semi-private courses, which are expected to be doing the most peak-load pricing. The 
magnitudes are largest for resort and private courses. This may seem anomalous, but it is actually consistent with the theory. Recall that the average weekend premium is about the same for all courses when there is a premium. When there is differential pricing, more of it is due to peak-load pricing at public and semi-private courses than at private courses and resorts. Hence, the responsiveness of the price differentials to competition should be less when there is more peak-load pricing.

For example, assume that the weekend markup is 20 percent at both a public course and at a resort course. However, at the public course, half is due to peak-load pricing and half to discrimination, while at the resort course 75 percent of the premium is discrimination. If a change in competition cuts the ability to discriminate in half, the change in the premium will be 5 percentage points at the public course and 7.5 percentage points at the resort. The difference in the magnitudes of the coefficient estimates is consistent with the theory.

Finally, the Pebble Beach variables - i.e., the availability of caddies and the environmental variables - are also fairly consistent between Tables 4 and 5 . The caddie variable is significant in the private and semi-private equations. The environmental variables are not as strong as in Table 4. However, only in the private-course regression are none of the environmental variables significant. 


\section{Conclusion}

This study examines the determinants of weekend and weekday price differentials in the golf industry by analyzing factors that shift demand between weekday and weekend play and factors that reflect differences in potential marginal revenue. Market competition is the most important factor of the latter. Our results indicate that an increase in the amount of competition from rival courses reduces the weekend price premium and is therefore an indication of price discrimination. As income increases so does the amount of differential pricing, which is arguably evidence of price discrimination.

On the other hand, resort courses and courses in areas with more tourism have less differential pricing between weekdays and weekends, which indicates that tourism smoothes demand across the peak and off-peak periods. This says that at least some of the weekend premium is a peak-load pricing phenomenon.

Both peak-load pricing and price discrimination are found in the golf industry, and we find that our results are consistent with the theory and literature on these pricing practices. A logical extension of this analysis would be to analyze other industries where pricing differentials occur across different times rather than the traditional 24-hour timeof-day pricing of electricity markets. Potential industries of analysis would be entertainment parks, theaters, and sports ticket sales. 


\section{Acknowledgements}

We thank Bobby McCormick, Matt Lindsay, Robert Tollison, John Warner, and Todd Kendall for helpful comments on previous drafts. We also thank the editor, Larry White, and referees at this journal. Any mistakes are our own.

\section{References}

Arellano, M. \& Serra, P. (2007a). A Model of Market Power in Electricity Industries Subject to Peak Load Pricing. Energy Policy, 35(10), 5130-5135

Arellano, M. \& Serra, P. (2007b). Spatial Peak-load Pricing. Energy Policy, 29(2), 228239

Bailey, E. E. \& White, L. J. (1974). Reversals in Peak and Offpeak Prices. Bell Journal. Spring

Baumol, W. J. \& Willig, R. D. (1981). Fixed Costs, Sunk Costs, Entry Barriers, and Sustainability of Monopoly The Quarterly Journal of Economics, 96(3), 405-431

Bergstrom, T. \& MacKie-Mason, J. K. (1991). Some Simple Analytics of Peak-Load Pricing. The RAND Journal of Economics, 22(2), 241-249

Berry, D. M. \& Mixon, Jr, F. G. (1999). Multiproduct Outputs and Scale Economies in Electric Power Production: Some New Estimates. Review of Industrial Organization 15(1), 65-76

Borenstein, S. (1985). Price Discrimination in Free-Entry Markets. RAND Journal of Economics, 16, 380-397

Borenstein, S. \& Rose, N. L. (1994). Competition and Price Dispersion in the U.S. Airline Industry. Journal of Political Economy, 102(4), 653-683

Borzekowski, R., Thomadsen, R. \& Taragin, C. (2009). Competition and Price Discrimination in the Market for Mailing Lists. Quantitative Marketing and Economics, 7, 147-149

Buchanan, J. M. (1966). Peak Loads and Efficient Pricing: Comment The Quarterly Journal of Economics, 80(3), 463-471

Busse, M. \& Rysman, M. (2005). Competition and Price Discrimination in Yellow Pages Advertising. The RAND Journal of Economics, 36(2), Summer, 378-390

Chong, E., Huet, F., Saussier, S., \& Steiner, F. (2004). Public-Private Partnerships and Prices: Evidence from Water Distribution in France Review of Industrial Organization, 29, 149-169 
Escobari, D. (2009). Systematic Peak-load Pricing, Congestion Premia and Demand Diverting: Empirical Evidence. Economics Letters, 103(1), 59-61

Gilbert, R. \& Newbery, D. (2008). Analytical Screens for Electricity Mergers. Review of Industrial Organization, 32, 217-239

Hirshleifer, J. (1958). Peak Loads and Efficient Pricing: A comment. The Quarterly Journal of Economics, 72(3), 451-462

Leslie, P. (2004). Price Discrimination in Broadway Theater The RAND Journal of Economics, 35(3), 520-531

Limehouse, F. F., Melvin, P. C., \& McCormick, R. E. (2010). The Demand for Environmental Quality: An Application of Hedonic Pricing in Golf Journal of Sports Economics, 11, 261 - 286

Maloney, M. T. (2001). Economies and Diseconomies: Estimating Electricity Cost Functions. Review of Industrial Organization, 19(2), 165-180

Mulligan, J. G. (2001). The Pricing of a Round of Golf: The Inefficiency of Membership Fees Revisited Journal of Sports Economics, November, 2(4), 328-340

Shepard, A. (1991). Price Discrimination and Retail Configuration Journal of Political Economy, 99(1), 30-53

Shmanske, S. (1998). Price Discrimination at the Links Contemporary Economic Policy, 16(3), 368-378

Shmanske, S. (2004). Market Preemption and Entry Deterrence: Evidence from the Golf Course Industry International Journal of the Economics of Business, 11(1), February, 55-68

Stavins, J. (2001). Price Discrimination in the Airline Market: The Effect of Market Concentration The Review of Economics and Statistics, 83(1), 200-202

Steiner, P. O. (1957). Peak Loads and Efficient Pricing The Quarterly Journal of Economics, 71(4), 585-610 
Table 1. Model Variables, Effect and Expected Signs

\begin{tabular}{lc}
\hline Price Discrimination Variables: & Expected Sign \\
\hline Competition & - \\
Income & + \\
Population & + \\
Population Density & - \\
Peak-Load Pricing Variables: & \\
\hline Tourism & - \\
Closed Mondays & - \\
Caddie Available & - \\
Environmental Variables & - \\
Course Types: & \\
$\quad$ Public & \\
$\quad$ Semi-private & + \\
$\quad$ Private & + \\
Resort & - \\
\hline
\end{tabular}

Notes: Other variables are included as controls without effect or sign predictions. 
Table 2. Summary Statistics

\begin{tabular}{|c|c|c|c|c|}
\hline Variable & Mean & Std. Dev. & Min. & Max. \\
\hline Green Fees: $\ln ($ Weekend/Weekday) & 0.152 & 0.146 & 0 & 1.072 \\
\hline Competition: Other Courses in Market Area & 97.075 & 118.377 & 1 & 451 \\
\hline Per Capita Income & 29.494 & 6.443 & 13.578 & 68.761 \\
\hline Density: Population per Square Mile & 0.801 & 1.482 & 0.001 & 34.917 \\
\hline Population & 2.381 & 4.000 & 0.003 & 1830.000 \\
\hline Tourism: Accommodation Employment Per Capita & 0.007 & 0.013 & 0.000 & 0.211 \\
\hline Average Rain & 38.632 & 12.258 & 2.99 & 119.527 \\
\hline Men's Slope & 120.475 & 8.070 & 73 & 149 \\
\hline Dress Code Enforced & 0.549 & 0.498 & 0 & 1 \\
\hline Aerate & 0.990 & 0.100 & 0 & 1 \\
\hline Driving Range & 0.830 & 0.375 & 0 & 1 \\
\hline Bar & 0.908 & 0.290 & 0 & 1 \\
\hline Homes on Course & 0.433 & 0.496 & 0 & 1 \\
\hline Closed Monday & 0.193 & 0.395 & 0 & 1 \\
\hline Caddie Available & 0.118 & 0.323 & 0 & 1 \\
\hline Audubon Sanctuary & 0.042 & 0.201 & 0 & 1 \\
\hline Environmental Planning Only & 0.034 & 0.182 & 0 & 1 \\
\hline Environmental Planning Plus & 0.016 & 0.126 & 0 & 1 \\
\hline Resort & 0.054 & 0.226 & 0 & 1 \\
\hline Private & 0.362 & 0.481 & 0 & 1 \\
\hline Semi-private & 0.150 & 0.357 & 0 & 1 \\
\hline Public & 0.434 & 0.496 & 0 & 1 \\
\hline
\end{tabular}

Notes: Observations: 7,536. Green Fees include cart. Log of ratio of weekend to weekday fees gives the weekend premium in percentage terms. Income in $\$ 1000$ s. Population per square mile in 1000s. Population in 100,000s. Average rain in inches per year. Environmental variables follow Limehouse, Melvin, and McCormick (2010).

Table 3. Differential Pricing by Course Type

\begin{tabular}{|c|c|c|c|c|}
\hline \multirow[b]{2}{*}{ Type } & \multirow{2}{*}{$\begin{array}{c}\text { Percent of Courses } \\
\text { with Different Green } \\
\text { Fees on Weekends }\end{array}$} & \multicolumn{2}{|c|}{ Green Fees: $\ln ($ Weekend/Weekday $)$} & \multirow[b]{2}{*}{ Observations } \\
\hline & & All Courses & Only if Different & \\
\hline Public & 0.78 & 0.17 & 0.21 & 3268 \\
\hline Semi-private & 0.76 & 0.19 & 0.24 & 1130 \\
\hline Private & 0.49 & 0.12 & 0.25 & 2731 \\
\hline Resort & 0.48 & 0.11 & 0.23 & 407 \\
\hline
\end{tabular}

Notes: Total observations: 7,536. 
Table 4: Determinants of Pricing on the Golf Course

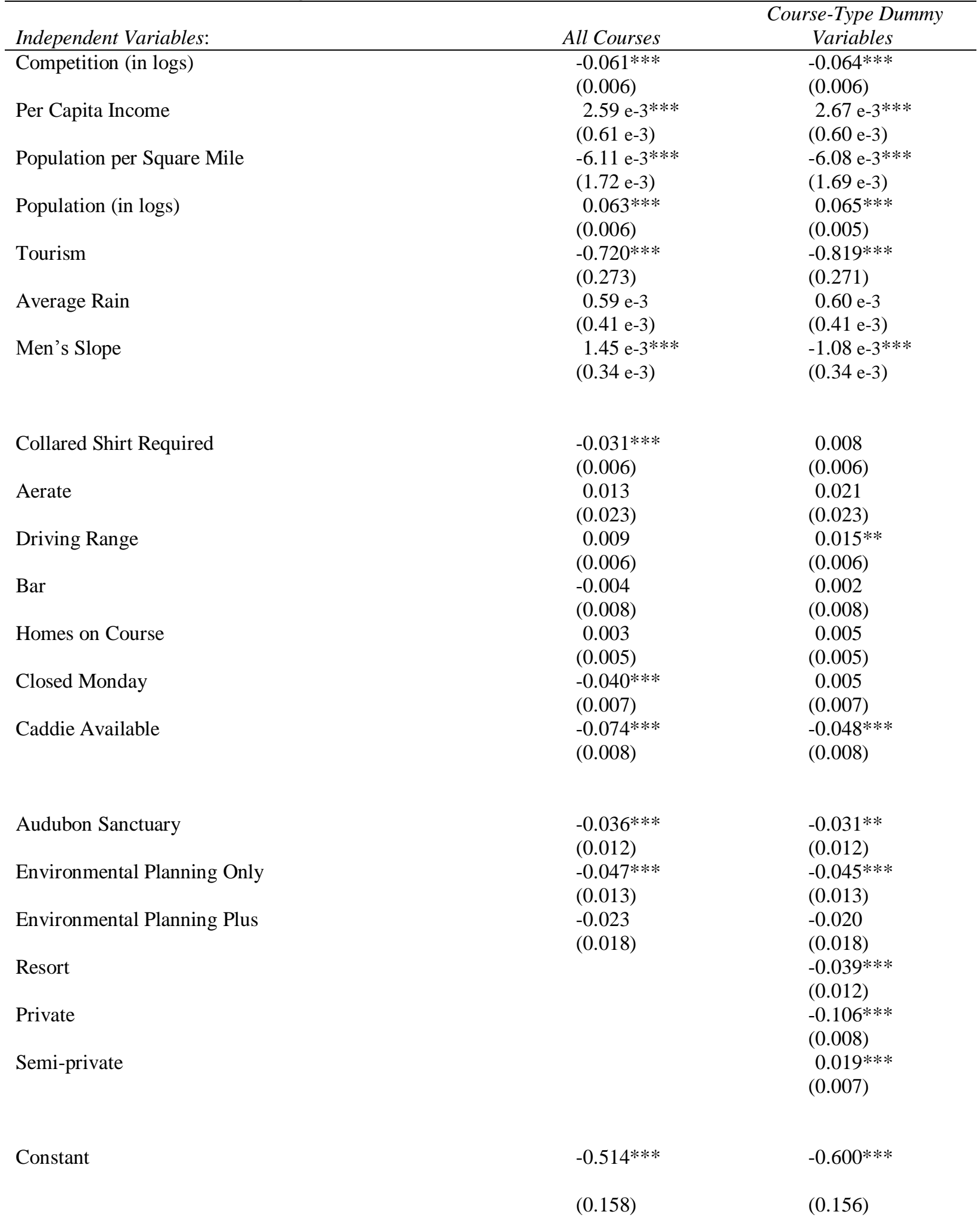


Table 4: Determinants of Pricing on the Golf Course

\begin{tabular}{|c|c|c|}
\hline \multirow{2}{*}{ Independent Variables: } & \multicolumn{2}{|c|}{ Course-Type Dummy } \\
\hline & All Courses & Variables \\
\hline Pseudo $R^{2}$ & 0.185 & 0.202 \\
\hline \multicolumn{3}{|c|}{$\begin{array}{l}\text { Notes: Dependant Variable is the natural log of the ratio of Weekend-to-Weekday Green Fees. Independent variable } \\
\text { magnitudes as reported in Table } 1 \text {. Competition is measured by other courses in market area. Tourism measured by } \\
\text { accommodation employment per capita in market area. Tobit regressions; } 7536 \text { observations; state fixed effects included. } \\
\text { Standard errors in parentheses; * significant at } 10 \% ; * * \text { significant at } 5 \% ; * * * \text { significant at } 1 \% \text {. State fixed effects significant } \\
\text { based on } F \text {-test. Pseudo } R^{2} \text { based on regression of actual on tobit predicted values. }\end{array}$} \\
\hline
\end{tabular}


Table 5: Determinants of Pricing on the Golf Course, Separated by Course Type

\begin{tabular}{|c|c|c|c|c|}
\hline Independent Variables: & Public & Semi-private & Private & Resort \\
\hline \multirow[t]{2}{*}{ Competition (in logs) } & $-0.022 * * *$ & $-0.066 * * *$ & $-0.116 * * *$ & $-0.135 * * *$ \\
\hline & $(0.008)$ & $(0.013)$ & $(0.017)$ & $(0.037)$ \\
\hline \multirow[t]{2}{*}{ Per Capita Income } & $2.22 \mathrm{e}-3 * * *$ & $4.64 \mathrm{e}-3 * * *$ & $3.42 \mathrm{e}-3 * * *$ & $-4.52 \mathrm{e}-3$ \\
\hline & $(7.07 \mathrm{e}-4)$ & $(1.66 \mathrm{e}-3)$ & $(1.28 \mathrm{e}-3)$ & $(3.84 \mathrm{e}-3)$ \\
\hline \multirow[t]{2}{*}{ Population per Square Mile } & -5.28 e- $3 * * *$ & -1.79 e- $2 *$ & -4.79 e- 3 & $3.79 \mathrm{e}-2$ \\
\hline & $(1.56 \mathrm{e}-3)$ & $(1.08 \mathrm{e}-2)$ & $(4.89 \mathrm{e}-3)$ & $(3.00 \mathrm{e}-2)$ \\
\hline \multirow[t]{2}{*}{ Population (in logs) } & $0.022 * * *$ & $0.064 * * *$ & $0.129 * * *$ & $0.116 * * *$ \\
\hline & $(0.007)$ & $(0.011)$ & $(0.014)$ & $(0.031)$ \\
\hline \multirow[t]{2}{*}{ Tourism } & $-1.103 * * *$ & -0.983 & -0.382 & $-2.905 * *$ \\
\hline & $(0.284)$ & $(0.631)$ & $(0.881)$ & $(1.375)$ \\
\hline \multirow[t]{2}{*}{ Average Rain } & $0.33 \mathrm{e}-3$ & $0.76 \mathrm{e}-3$ & $1.66 \mathrm{e}-3$ & $2.31 \mathrm{e}-3$ \\
\hline & $(0.47$ e-3) & $(0.91 \mathrm{e}-3)$ & $(1.02 \mathrm{e}-3)$ & $(1.68$ e-3) \\
\hline \multirow[t]{2}{*}{ Slope Men's } & -0.25 e- 3 & -2.00 e- $3 * *$ & -2.63 e- $3 * * *$ & -2.48 e-3 \\
\hline & $(0.36 \mathrm{e}-3)$ & $(0.82 \mathrm{e}-3)$ & $(0.90 \mathrm{e}-3)$ & $(1.69 \mathrm{e}-3)$ \\
\hline \multirow[t]{2}{*}{ Collared Shirt Required } & $0.022 * * *$ & -0.004 & $0.060 * *$ & 0.007 \\
\hline & $(0.007)$ & $(0.012)$ & $(0.024)$ & $(0.035)$ \\
\hline \multirow[t]{2}{*}{ Aerate } & 0.033 & 0.026 & 0.018 & 0.039 \\
\hline & $(0.027)$ & $(0.047)$ & $(0.059)$ & $(0.088)$ \\
\hline \multirow[t]{2}{*}{ Driving Range } & $0.019 * * *$ & 0.017 & -0.026 & 0.058 \\
\hline & $(0.006)$ & $(0.014)$ & $(0.022)$ & $(0.043)$ \\
\hline \multirow[t]{2}{*}{ Bar } & -0.003 & 0.010 & 0.022 & $0.139 * *$ \\
\hline & $(0.008)$ & (0.019) & $(0.028)$ & $(0.069)$ \\
\hline \multirow[t]{2}{*}{ Homes on Course } & $0.012 * *$ & 0.013 & $-0.024 * *$ & $0.095 * * *$ \\
\hline & $(0.006)$ & $(0.012)$ & $(0.011)$ & $(0.029)$ \\
\hline \multirow[t]{2}{*}{ Closed Monday } & -0.019 & -0.026 & -0.011 & 0.083 \\
\hline & $(0.021)$ & $(0.023)$ & $(0.011)$ & $(0.093)$ \\
\hline \multirow[t]{2}{*}{ Caddie Available } & -0.023 & $-0.077 * *$ & $-0.058 * * *$ & -0.087 \\
\hline & $(0.020)$ & $(0.038)$ & $(0.014)$ & $(0.063)$ \\
\hline \multirow[t]{2}{*}{ Audubon Sanctuary } & -0.019 & 0.027 & -0.029 & $-0.180 * * *$ \\
\hline & $(0.017)$ & $(0.047)$ & $(0.022)$ & $(0.054)$ \\
\hline \multirow[t]{2}{*}{ Environmental Planning Only } & $-0.058 * * *$ & $-0.096 * *$ & -0.009 & $-0.205 *$ \\
\hline & $(0.015)$ & $(0.044)$ & $(0.024)$ & $(0.105)$ \\
\hline \multirow[t]{2}{*}{ Environmental Planning Plus } & -0.012 & 0.004 & -0.031 & 0.005 \\
\hline & $(0.024)$ & $(0.055)$ & $(0.036)$ & $(0.073)$ \\
\hline \multirow[t]{2}{*}{ Constant } & $-0.250 *$ & $-0.494 * *$ & $-1.169 * * *$ & -0.517 \\
\hline & $(0.140)$ & $(0.229)$ & $(0.241)$ & $(0.374)$ \\
\hline Pseudo $R^{2}$ & 0.221 & 0.258 & 0.234 & 0.356 \\
\hline Observations & 3,268 & 1,130 & 2,731 & 407 \\
\hline
\end{tabular}

Notes: Dependant Variable is the natural log of the ratio of Weekend-to-Weekday Green Fees. Independent variable magnitudes as reported in Table 1. Tobit regressions; state fixed effects included. Standard errors in parentheses: * significant at $10 \%$; ** significant at $5 \%$; *** significant at $1 \%$. State fixed effects significant based on $F$-test. Pseudo $R^{2}$ based on regression of actual on tobit predicted values. 